\title{
The Economics of Lender Liability
}

\author{
Daniel R. Fischel $\dagger$
}

\section{INTRODUCTION}

In July 1986, the Hunt Brothers of Dallas, Texas, weakened by losses in the silver and oil markets, defaulted on a $\$ 1.5$ billion loan. The Hunts then filed a $\$ 3.6$ billion lawsuit against their lenders on theories, among others, of fraud, negligent misrepresentation, breach of fiduciary duty and duty of good faith, breach of contract, and violations of the antitrust laws and the Bank Holding Company Act. ${ }^{1}$ Ten years ago, the Hunt's action would have been wholly unprecedented, with virtually no probability of success. However, developments in the law since that time, in particular the emergence of the booming area of lender liability, have dramatically changed the conventional understanding of the relationship between lenders and their borrowers.

In recent years banks have been subjected to liability in a number of diverse situations. State National Bank of El Paso v. Farah Manufacturing $\mathrm{Co}^{2}$ is illustrative. William Farah was chief executive officer of FMC, a clothing company. From 1972-76, the company incurred large losses, and William Farah was subsequently replaced as GEO. In 1977, FMC and its three banks amended their outstanding loan agreements to provide that any change in FMC's top management considered by any of the banks to be adverse to their interests would constitute an act of default. The purpose of the management change clause was to prevent Farah from returning as CEO.

Shortly thereafter, however, Farah sought reinstatement as CEO. The board of directors refused after the lenders took the position that Farah's return would constitute a default under the management change clause. Approximately one year later, FMC and the banks restructured the loan and deleted the management change clause-Farah subsequently regained control of the company. Under Farah's leadership, FMC's fortunes changed dramatically for the better, and the company regained profitability.

† Lee and Brena Freeman Professor of Law; Professor of Law and Business, University of Chicago. The author would like to thank Alan Schwartz and David Ross for their helpful comments.

1. See Defendants' Memorandum of Law in Support of Penrod Banks' Renewed Motion for Partial Summary Judgment at 5, Hunt v. Bankers Trust Co. (No. 3-86-1684G) (N.D. Tex.). The case was eventually settled.

2. 678 S.W.2d 661 (Tex. Ct. App. 1984). 
FMC then commenced litigation against its lenders. FMC alleged that the lenders had not intended to declare a default but nevertheless blocked Farah's return, and that this action constituted fraud, duress, and interference with business relations. The jury agreed, awarding approximately $\$ 19$ million to FMC. The Texas Court of Appeals affirmed.

K.M.C. Co. v. Iroing Trust $\mathrm{Co}^{3}$ is another leading lender liability case. In 1979, Irving Trust and K.M.G., a wholesale and retail grocery business, entered into a financing agreement that provided K.M.G. with a line of credit to a maximum of $\$ 3.0$ million, later increased to $\$ 3.5$ million. In exchange, Irving received a security interest in all of K.M.C.'s accounts receivable and inventory, and K.M.G. was obligated to deposit its receipts in a "blocked account" controlled by Irving. The financing agreement further provided that all advances by Irving under the line of credit were discretionary and that the outstanding loans were payable on demand. Subject to this limitation, K.M.C. could draw on the line of credit under a formula based on a percentage of the value of its inventory and eligible receivables.

On March 1, 1982, K.M.C. requested an $\$ 800,000$ advance, which if given would have raised the outstanding balance to just under $\$ 3.5$ million. Irving refused at first, but on March 4, just three days later, Irving agreed to advance an additional $\$ 700,000$. K.M.C.'s business soon collapsed. K.M.G. subsequently sued Irving, claiming that Irving's refusal to advance the requested funds on March 1 without prior notice constituted a breach of the duty of good faith, and that this refusal ultimately caused K.M.G.'s demise. The jury agreed and awarded $\$ 7.5$ million to K.M.C. The Sixth Circuit affirmed, holding that Irving should have given K.M.C. notice before refusing to advance additional funds on March $1 .^{4}$ The Sixth Circuit further stated that a lender's ability to demand repayment is subject to a good faith limitation. ${ }^{5}$

In an increasing number of other well-publicized trials, juries-and occasionally courts in non-jury trials-have awarded borrowers staggering amounts in lender liability suits against banks. ${ }^{6}$ While some of these verdicts have been reversed on appeal, ${ }^{7}$ the basis for reversal in these cases

3. 757 F.2d 752 (6th Cir. 1985).

4. Id. at 759 .

5. Id. at 760 .

6. For examples of some of the major awards against banks in lender liability cases, see Conlan v. Wells Fargo (No. 82852) (Cal. App. Dep't Super. Ct. June 10, 1987) (jury award to borrower of $\$ 10$ million in compensatory damages and $\$ 50$ million in punitive damages); Jewell v. Bank of America, (No. 112439) (Cal. App. Dep't Super. Ct. 1986) (jury award of $\$ 19$ in compensatory damages and $\$ 27$ million in punitive damages); FDIC v. Scharenberg (Nos. 84-2712, 87-0211, 87-0238) (S.D. Fla. April 29, 1987) (\$105 million in compensatory damages); and Penthouse Int'l v. Dominion Fed. Sav. \& Loan Assoc. (No. 84-Giv. 4325) (S.D.N.Y. July 29, 1987) (amended opinion July 30, 1987) (court in bench trial awarded $\$ 130$ million); Robinson v. McAllen State Bank (No. C-1948-84-D) (Tex. Dist. Ct. 1987) (verdict of $\$ 10$ million in compensatory damages and $\$ 50$ million in punitive damages).

7. See Penthouse Int'l v. Dominion Fed. Sav. \& Loan Assoc., 855 F.2d 963 (2d Cir. 1988) (dam- 
has been limited to the facts of each case. The area of lender liability remains a booming area of intense concern to lenders and students of commercial law. ${ }^{8}$

Lender liability cases have led to the creation of an area of commercial law that has not been accompanied by the development of a coherent theoretical framework establishing the rights of lenders and their duties to their borrowers. ${ }^{2}$ For example, what is the purpose of contractual provisions included in loan agreements and who benefits from these provisions? And to what extent do concepts like good faith and fiduciary duty, frequently discussed in lender liability cases, supplement or override contractual provisions in loan agreements? The cases and commentary in the lender liability area provide no satisfactory answers to these questions.

The subject of damages is also in serious need of attention. Many lender liability cases involve awards of compensatory damages far in excess of the loan in question. Punitive damages are also awarded frequently. These awards present a conundrum. Borrowing does not create wealth: If I borrow $\$ 100$ at the market rate of interest, I am no wealthier than I was before. Under what circumstances, then, can the failure of a bank to lend $\$ 100$ result in any compensatory damages, let alone damages in excess of $\$ 100$ ? And what are the consequences of increasing whatever the compensatory damages are by an award of punitive damages?

Until some basis exists for answering these questions, the area of lender liability will remain hopelessly muddled. The purpose of this essay is to use principles of economics to illuminate these murky issues.

\section{The Economics of the Lender-Borrower Relationship}

\section{A. Exogenous Events, Debtor Misbehavior and the Problem of Default Risk}

Every lender, when deciding whether to make a loan and on what terms that loan should be made, must assess the probability that a particular borrower will default. The likely recovery in the event of default

age verdict reversed because evidence did not establish that lender had contractual obligation to lend); Kruse v. Bank of America, 202 Cal. App. 3d 38, 248 Cal. Rptr. 217 (1988) (damage verdict reversed because evidence did not establish that lender engaged in fraud or breached contract to lend).

8. See, e.g., Lender Liability Litigation 1988: Recent Developments 14-40 (PLI Commercial Law \& Practice Handbook No. 468, Order No. A4-4238); Ebke \& Griffin, Lender Liability to Debtors: Taward a Canceptual Framework, 40 Sw. L.J. 775 (1986); Special Project Note, Lenders Liability, 42 VAND. L. REv. 853 (1989); Note, The Growth of Lender Liability: An Economic Perspective, 21 GA. L. REv. 723 (1987); Note, K.M.C. Co. v. Irving Trust Co.: Discretionary Financing and the Implied Duty of Good Faith, 81 Nw. U.L. REv. 539 (1987); Comment, What's So Good about Good Faith: The Good Faith Performance Obligation in Commercial Lending, 55 U. CHI. L. REV. 1335 (1988).

9. For illustrative leading articles analyzing the debtor-creditor relationship in other contexts, see, e.g., Schwartz, The Enforceability of Security Interests in Consumer Goods, 26 J.L. \& EcoN. 117 (1983); Scott, Rethinking the Regulation of Coercive Creditor Remedies, 89 Colum. L. REv. 730 (1989). 
must also be assessed. While these matters are of critical importance, the ability of the lender to make correct assessments is severely limited, no matter how diligent the lender may be. The reason for this difficulty is that events after the loan is made will affect the probability of default and the likelihood of recovery if default occurs. These events are of two general types: (1) exogenous events; and (2) debtor misbehavior.

The effect of exogenous events such as dramatic changes in market or industry conditions (i.e., a recession or a sharp decline in the price of oil) is clear. These events can significantly affect the probability of default and the likely recovery if a default occurs.

The effect of debtor misbehavior is also straightforward. Debtors have an incentive to engage in several types of misbehavior once a loan has been made:10

(1) Asset withdrawal. Once a lender contributes capital to a firm, the borrower has an incentive to withdraw assets from the firm by, for example, declaring a dividend for the amount of the loan. This harmful incentive structure is exacerbated in situations involving extensions of credit to firms with limited liability;

(2) Risky investment policy. The existence of debt creates an incentive for borrowers to invest in riskier projects. This incentive arises because the lender bears the downside risk if the project turns out poorly, but he does not share in the upside potential if the project turns out well. In other words, before the loan was made, the borrower bore the costs of risky investments that failed; now these costs are shared with the lender. Before and after the extension of credit, however, the borrower alone obtains the benefit from risky investments that succeed.

This incentive to invest in risky projects is a direct function of the amount the borrower has at risk-the size of the equity cushion. In the extreme case in which the value of the firm equals the value of outstanding debt, the firm has nothing to lose and everything to gain by adopting a "shoot the moon" investment strategy;

(3) Claim dilution. The value of debt is a function, inter alia, of the amount of other debt. The greater the amount of debt of the same or higher seniority, the lower the value of debt. Thus a borrower can reduce the value of outstanding debt by issuing more debt and thereby diluting the claims of existing creditors; and

(4) Underinvestment. The creation of debt imposes an additional claimant on the firm's income stream. This additional claim can result in the

10. For a discussion of the conflict of interest between equity claimants and borrowers and the contractual mechanisms for minimizing the problem, see Smith \& Warner, On Financial Contracting: An Analysis of Bond Covenants, 7 J. FIN. EcoN. 117 (1979); see also Jensen \& Meckling, Theory of the Firm: Managerial Behavior, Agency Costs, and Ownership Structure, 3 J. Fin. ECoN. 305 (1976).

11. For an analysis of the incentives created by limited liability, see Easterbrook \& Fischel, Limited Liability and the Corporation, 52 U. CHI. L. Rev. 89 (1985). 
borrower failing to invest in a profitable investment project if too much of the benefit from the project will accrue to the lender. In this event, the value of outstanding debt will again be reduced because of the borrower's actions.

At first blush, the two types of events that can adversely affect lenders after credit has been extended-exogenous events and debtor misbehavior-seem completely unrelated. In reality, however, there is a close relationship between the two. As exogenous events adversely affect the borrower, the probability of debtor misbehavior increases. This point can best be illustrated by a simple numerical example: Consider a hypothetical company with capital of $\$ 200$, consisting of equal $\$ 100$ contributions of debt and equity. Now assume that the company suffers a $\$ 100$ decline in value as a result of a recession. The remaining $\$ 100$ of value is just enough to pay off the lender.

Although debtor misbehavior did not cause the $\$ 100$ decline in value, this decline will have a profound effect on the borrower's incentives. For example, as discussed above, the borrower's incentive to invest in risky projects increases as the value of the debt falls, because the borrower now has less of its own funds at risk. Returning to the example, the borrower would not have been likely to have accepted a project with a negative net present value of less than $\$ 100$ when the firm was worth $\$ 200$ because the borrower would bear the loss. However, once the value of the firm has fallen to $\$ 100$, the borrower might be willing to invest in a project with some upside potential even if its expected value is negative because the loss is borne by the lender. Furthermore, if the value of the firm falls below $\$ 100$, the borrower may even reject some positive net present value projects due to the underinvestment problem. Because the benefits of the investment in this situation go to the lender, the borrower has no incentive to proceed.

Similarly, the probability that the declaration of a dividend or an increase in the amount of outstanding debt will hurt existing creditors is a function of the value of the borrower not represented by debt. The lower the equity cushion, the greater the probability that these actions will harm existing creditors. Thus, if the equity cushion is eroded or eliminated entirely, as in the above example by adverse market or industry developments, actions such as withdrawal of assets will impose greater harm on existing creditors.

\section{B. The Role of Monitoring and Bonding}

The ability of borrowers to take actions adverse to lenders after a loan has been made does not mean that borrowers can victimize lenders. On the contrary, lenders anticipate the various forms of debtor misbehavior and factor them into their decisions of whether and on what terms to lend. 
The greater the amount of anticipated debtor misconduct, the greater the compensation (i.e., the higher interest rate) that a lender will demand.

To decrease the amount of compensation demanded, borrowers will attempt to allay lenders' concerns by agreeing to various monitoring and bonding mechanisms. ${ }^{12}$ An illustration of a monitoring mechanism is an agreement whereby the borrower promises to provide the lender with periodic financial information so that the lender can make more informed decisions. Examples of bonding mechanisms include the provision of personal guarantees and/or security for the loan, as well as various types of loan covenants limiting the discretion of the borrower.

Some loan covenants are very specific in the sense that they refer to particular behavior by the debtor; covenants establishing the circumstances when dividends can be paid and the provision at issue in Farah prohibiting a management change without consent of the lender are examples of this type. Other covenants, like the ones at issue in $K . M . C$., are very general. There, the relevant covenants in a letter of credit agreement gave the lender sole discretion whether to continue to lend and the ability to call amounts outstanding as immediately due and payable.

It is important to understand that these bonding mechanisms limiting the discretion of the borrower are not "unfair" to the borrower in any meaningful sense. ${ }^{13}$ The opposite is true, because the borrower obtains credit on more advantageous terms as a result of the protections afforded the lender by the loan covenants. Unconscionability is rarely a serious concern in multi-million dollar commercial loan transactions. Moreover, the borrower always has the option of not borrowing or of obtaining financing elsewhere. Credit markets are intensely competitive; alternative sources of credit abound. Thus the willingness of the borrower to go forward with a transaction which includes loan covenants is strong, perhaps dispositive, evidence that the borrower believes he will benefit from the covenants relative to his alternatives.

Thus in Farah, the lender apparently concluded that the default risk would be increased if Farah regained control and therefore the bank insisted on including a management change clause as part of the agreement. While the management change clause ostensibly protected the lender, it also benefitted the borrower by reducing the compensation demanded by the lender.

The analysis of the loan covenants at issue in K.M.C. is similar to the analysis of Farah, but it is less intuitively clear because of the total discretion vested in the lender. Why would any borrower agree to such provisions which on their face give the lender sole discretion over whether to

12. See Jensen \& Meckling, supra note 10.

13. For a similar analysis of monitoring and bonding mechanisms in the context of franchise agreements, see Klein, Transaction Cost Determinants of "Unfair" Contractual Arrangements, 70 AM. ECON. Rev. 356 (May, 1980). 
lend and whether to call the outstanding amount? The reason is that the costs of writing and enforcing contracts make it impossible to deter all forms of debtor misbehavior in the initial agreement. ${ }^{\mathbf{1 4}}$ Therefore, to avoid prohibitively expensive contract terms and gain more favorable interest rates, borrowers are willing to concede such provisions to lenders.

Consider the situation when the parties want to negotiate a letter of credit agreement under which the borrower can request funds over several years. One way to structure the agreement would be to allow the borrower an unconditional right to demand funds at any time throughout the duration of the agreement under terms fixed at the outset. The difficulty is that this arrangement subjects the lender to the risk of subsequent debtor misbehavior and/or exogenous events that increase default risk.

A second possibility that provides some protection to the lender (and which therefore decreases the compensation the lender will demand) is for the letter of credit agreement to state specifically when the lender is obligated to advance funds. This arrangement will not be entirely satisfactory either, however, because it is difficult to specify in advance an appropriate response by the lender to all future contingencies. One partial solution to this problem is to include in the agreement general language requiring the lender to lend unless there is a material adverse change in the condition of the borrower. But this solution creates problems of its own because disputes may arise concerning what constitutes a "material adverse change" and because some third party such as a court must be the ultimate arbiter.

Still another solution to the "cost of contracting" problem, the one chosen by the parties in K.M.C., is to structure the agreement so that the lender controls whether to lend and the length of time amounts advanced will remain outstanding (the ability to call the loan). The lender in K.M.C. was further protected by the "blocked account" mechanism which denied the borrower access to the funds that provided security for the loan. While these provisions impose costs of their own, ${ }^{15}$ they do protect the lender from increased default risk resulting from debtor misbehavior and/or exogenous events. Borrowers also benefit from such provisions because the compensation lenders demand for bearing default risk is reduced. Further, such provisions enable borrowers who are confident about their prospects to signal their beliefs to lenders and thus to borrow on more attractive terms than borrowers who are less optimistic.

14. For a general discussion of contractual adaptations when the costs of writing and enforcing contracts make it impossible to cover all contingencies that may arise, see Goetz \& Scott, Principles of Relational Contracts, 67 VA. L. REV. 1089 (1981). See also Klein, supra note 13.

15. See infra pp. 138-140. 


\section{The Problem of Lender Misbehavior}

Thus far I have emphasized how the problem of debtor misbehavior creates an incentive for borrowers to enter into various monitoring and bonding mechanisms in order to obtain credit on more favorable terms. It would be a mistake, however, to assume that these monitoring and bonding mechanisms operate costlessly.

Monitoring and bonding mechanisms impose several types of costs that limit their use. The first type is direct cost-the cost, for example, of direct audits. The fact that audits are costly ensures they will be conducted periodically rather than continuously. A second type of cost is opportunity cost, the benefit foregone from restrictions on the borrower's discretion. The management change clause in Farah, for example, limited the borrower's flexibility to implement wealth increasing changes of the management team. Other types of restrictions, particularly restrictions on investment policy, are costly for the same reason, and therefore should be used economically.

A third, and for my purposes most important, cost of monitoring and bonding mechanisms is the incentive they create for the lender to misbehave by acting opportunistically. Opportunistic behavior occurs whenever one party attempts to obtain, at the expense of the other, a benefit not contemplated by the initial agreement, either explicitly or implicitly. ${ }^{16}$ Thus, whenever a lender attempts to renegotiate with the borrower for better terms when there is no basis for doing so, the lender is behaving opportunistically.

Three factors limit the ability of the lender to behave opportunistically to extract additional concessions from the borrower. First, if the lender's actions constitute a breach of contract, the lender can be forced to pay damages. Second, the lender must be concerned about the effect of opportunistic behavior on its reputation. Most lenders are typically larger than borrowers and more likely to be repeat players. Reputation will be a more effective deterrent to lender misbehavior, therefore, than to debtor misbehavior. ${ }^{17}$ Finally, the market for substitute performance or, more specifically, the availability of other sources of credit, limits lenders' ability to extract concessions from debtors. The size of any concessions must be smaller than the costs to the debtor of negotiating with a new lender. ${ }^{18}$

While these three factors weaken the incentive for a lender to behave opportunistically, they do not eliminate it altogether. Not all attempts to

16. For a thorough analysis of the problem of opportunistic behavior, see Muris, Opportunistic Behavior and the Law of Contracts, 65 MiNN. L. REv. 521 (1981).

17. For a similar argument that reputation deters opportunistic behavior by employers who also tend to be repeat players and larger than employees, see Epstein, In Defense of the Contract at Will, 51 U. CHI. L. REv. 947, 967-68 (1984).

18. See infra pp. 138-140 (discussing how ability of new lender in bankruptcy to obtain superpriority also limits ability of lender to behave opportunistically). 
behave opportunistically will constitute breaches; many will be more subtle. Nor is reputation a complete answer since actions by the lender will often prove ambiguous in their justification. It will frequently be difficult, in other words, for future borrowers to draw inferences from lenders' past actions. Further, reputation will be a weak deterrent for lenders who do not intend to transact in the future. Finally, the availability of alternative sources of credit is also not a complete solution. Since there are always some costs associated with negotiating with a new lender, the lender has some range in which to extract concessions.

There are two situations in which this range might be quite large because the costs to the borrower of negotiating with a new lender are high. The first concerns the occurrence of a change in exogenous events which alters the economics of the credit relationship where the risk of such change was initially allocated to the lender. For example, in a situation involving a fixed rate loan in which interest rates have risen dramatically, the lender has a strong incentive to repudiate the initial allocation of risks and renegotiate. The availability of other sources of credit provides limited comfort to the borrower since any new agreement will reflect the increased rate of interest.

The second situation in which the costs to the borrower of negotiating with a new lender may be high arises when the relationship between the initial lender and the borrower has become highly specialized over time. If the lender has acquired a great deal of costly information about the particular borrower and its prospects, it can loan on more advantageous terms than other lenders who are less informed. The advantage of the first lender will be even greater if the borrower is faced with time immediacy. Assume, for example, that a lender with specialized knowledge knows that a particular borrower plans to use the proceeds of a loan to purchase a unique asset on a certain date. The lender can then threaten not to lend the money unless the borrower renegotiates the terms of the loan, knowing that it will be very difficult for the borrower to obtain a new source of credit in time to purchase the unique asset.

Thus, it will be profitable in certain circumstances for a lender to behave opportunistically. Indeed, the probability of opportunistic behavior by lenders is increased by the presence of the very monitoring and bonding mechanisms designed to limit debtor misbehavior. The most obvious case in which this will be true is the situation (as in K.M.C.) where the agreement provides the lender with sole discretion to refuse to lend and to declare amounts outstanding immediately due and payable whether or not the debtor has misbehaved or is likely to do so in the future. Loan covenants that require the borrower to take certain actions and to refrain from others also increase the probability of opportunistic behavior by lenders. The number of such covenants will be larger as the ability of the lender to 
declare a technical default for the purpose of extracting concessions from the debtor expands.

Whether the increased risk of lender misbehavior created by loan covenants imposes costs that outweigh the benefits from limiting debtor misbehavior cannot be resolved at a theoretical level. The answer will vary depending on the situation and particular covenant involved. The most that can be said is that when such covenants are present, the parties must have concluded at the time of the initial agreement that the gains from deterring debtor misbehavior outweighed the costs from increasing the probability of lender misbehavior.

\section{Contract Law, The Duty Of Good Faith, and Fiduciary Duties}

Courts faced with a lender liability case must decide whether the challenged conduct of the lender was consistent with the agreement between the parties. This inquiry is primarily a matter of contract interpretation. What remains unclear, however, is whether courts should look beyond the contract itself and the usual tools of contract interpretation to some other body of authority in order to define the rights and duties between the parties. This question is important because borrowers in recent lender liability cases have argued that lenders' conduct violated the duty of good faith and fiduciary duties to the borrower. However, precisely what these concepts mean and what their relationship is to contract law is not clearly understood.

\section{A. The Duty of Good Faith}

The doctrine of good faith has a long history in contract law. Section 1203 of the Uniform Commercial Code provides that "[e]very contract or duty within this Act imposes an obligation of good faith in its performance or enforcement." ${ }^{19}$ Similarly, Section 205 of the Restatement (Second) of Contracts states that a duty of good faith should be imposed in all contracts. ${ }^{20}$

However, notwithstanding the extensive literature on the subject, ${ }^{21}$ no consensus exists on precisely what the duty of good faith means. At one extreme, some commentators have argued that the duty should be limited

19. U.C.C. §1-203 (1988).

20. Restatement (SECOND) of Contracts $§ 205$ (1981).

21. See, e.g., Burton, Breach of Contract and the Common Law Duty to Perform in Good Faith, 94 Harv. L. Rev. 369 (1980); Farnsworth, Good Faith Performance and Commercial Reasonableness Under the Uniform Commercial Code, 30 U. CHI. L. REv. 666 (1963); Gillette, Limitations on the Obligation of Good Faith, 1981 Duke L.J. 619; Summers, "Good Faith" in General Contract Law and the Sales Provisions of the Uniform Commercial Code, 54 VA. L. REv, 195 (1968); Comment, What's So Good About Good Faith? The Good Faith Performance Obligation in Commercial Lending, 55 U. CHI. L. Rev. 1335 (1988). 
to a prohibition of intentional dishonesty. ${ }^{22}$ Under this view, the duty of good faith adds little to the prohibition against fraud other than a vague exhortation for moral behavior. At the other extreme, several commentators have concluded that good faith should be interpreted expansively to incorporate community standards of fairness and decency. ${ }^{23}$ The obvious difficulty with this position is the lack of any accepted understanding of the meaning of these terms. Moreover, this lack of content creates an added risk that the fairness and decency standard will be applied arbitrarily to the detriment of lenders and borrowers alike. For example, a borrower-plaintiff might be able to invalidate default provisions used by borrowers to obtain more favorable credit terms on the grounds that they are "unfair," but this act would ultimately hurt borrowers as a class by raising the cost of credit.

An intermediate position is to interpret the duty of good faith as equivalent to a prohibition of opportunistic behavior. ${ }^{24}$ Under this view, lenders are entitled to the benefit of their bargain but are precluded from using contractual terms as a pretense for extracting benefits for which they have not bargained. For example, a lender such as the one in K.M.C. ${ }^{25}$ could terminate funding if the default risk increased, but, absent a risk increase, the duty of good faith would prevent the same lender from threatening to terminate funding in order to force the borrower to pay a higher interest rate.

Once again, the rationale for imposing a duty of good faith on lenders relates to the impossibility of drafting a contract covering every possible contingency. If contracts could be negotiated and enforced without any cost, the parties could negotiate an agreement which would preclude attempts by the lender to behave opportunistically. Because of the costs of negotiating and enforcing agreements, however, the parties cannot prevent all opportunistic behavior by contract. Thus the duty of good faith acts as an implied contractual term to achieve what the parties themselves cannot given the costs involved.

While this interpretation of the duty of good faith has a certain appeal, it is not without difficulty. The problem is that distinguishing opportunistic from non-opportunistic behavior can be very complicated if not impossible. ${ }^{28} \mathrm{~A}$ lender will never concede that its actions were designed to obtain a benefit not bargained for in the initial agreement. On the contrary,

\footnotetext{
22. See Gillette, supra note 21.

23. See Summers, supra note 21.

24. This interpretation of the duty of good faith is suggested in Muris, supra note 16. See also Goetz \& Scott, supra note 14.

25. See supra text accompanying note 3 .

26. The problem of distinguishing non-opportunistic exercise of contractual rights from opportunistic behavior is pervasive in the law of contracts. See, e.g., Aivazian, Trebilcock \& Penny, The Law of Contract Modifications: The Uncertain Quest for a Benchmark of Enforceability, 22 OsGOODE Hall L.J. 173 (1984); Easterbrook \& Fischel, Close Corporations and Agency Costs, 38 STAN. L. REv. 271, 297 n.66 (1986); Muris, supra note 16.
} 
the lender will claim that its refusal to continue funding was based on its assessment of the debtor and the probability of default. Moreover, not only will distinguishing between these two explanations be difficult, but also the attempt to distinguish them will impair the contractual protection given to the lender in the first instance.

Recall that provisions giving the lender sole discretion whether to continue funding and to call any amounts outstanding are best understood as bonding mechanisms used by the borrower to obtain more favorable credit terms. The strength of the bond, however, is weakened if the borrower can argue to a court that the exercise of discretion granted to the lender by the agreement was not done in good faith. This recourse defeats one of the key features of the bond: that the lender, and not a court, decides whether to continue the relationship with a particular borrower. On the other hand, allowing the lender absolute discretion, as discussed above, creates an incentive for the lender to behave opportunistically.

Thus there is a trade-off. The more absolute the discretion of the lender, the stronger the bond of the borrower but the greater the incentive of the lender to behave opportunistically. Conversely, the more expansive the interpretation of the duty of good faith to control opportunistic behavior by the lender, the weaker is the bond of the borrower and the less able the borrower is to use the bond to obtain more favorable credit terms. K.M.C. and Farah demonstrate that courts must be sensitive to this tradeoff when interpreting the duty of good faith.

\section{B. K.M.G., Farah and the Duty of Good Faith}

\section{K.M.C. Co. v. Irving Trust Co.}

K.M.C. illustrates the application of the duty of good faith in lender liability cases. There the Sixth Circuit held that the duty requires a lender to provide notice to the borrower before refusing to advance requested funds under a letter of credit agreement. The court rejected the lender's claim that this notice requirement was inconsistent with the demand provision in the agreement between the parties because it found that the lender's ability to demand repayment of amounts outstanding is limited by an obligation of good faith performance. Thus the Sixth Circuit concluded that Irving, the lender, violated its duty of good faith by refusing to advance requested funds without first providing notice.

The court's imposition of a notice requirement was apparently motivated by a concern that "the literal interpretation of the financing agreement" would leave "K.M.C.'s continued existence entirely at the whim or mercy of Irving. . . ."27 The rationale for this concern, however, is unclear. One possible explanation is that the court believed that the agree- 
ment as written was unconscionable because it provided the lender with discretion to refuse to advance funds. This rationale is not very satisfactory, however, because it begs the question of why a presumably sophisticated commercial borrower in a competitive credit market would consent to such an agreement in the first place. This enigma disappears, however, once it is understood that the discretion vested in the lender by the agreement is best understood as a bonding device which benefits both the borrower and the lender.

An alternative explanation for the court's interpretation of the duty of good faith is that a notice requirement is necessary to prevent opportunistic behavior by lenders. Under this interpretation, the court concluded that the notice requirement was in effect an implied contractual term that the parties would have agreed to if they had anticipated the situation in K.M.C. However, this interpretation of the court's holding also has serious difficulties.

First, it appears to be inconsistent with the actual agreement, which entrusts the decision whether to continue funding to the lender, not to a court. Second, under the facts of K.M.C., it is doubtful that the lender's decision is accurately characterized as opportunistic behavior. According to the evidence, it was not clear that K.M.G. would have been able to meet its obligations even had Irving advanced the requested $\$ 800,000 .^{28}$ Moreover, the deteriorating financial condition of the borrower during the period prior to the date that the lender refused to advance additional funds was undisputed. As the court stated: "It is plain from the record that the company was heavily leveraged, its heavy losses in $1981 \mathrm{had}$ eroded stockholder equity, and it had a substantial amount of uncollectible receivables in excess of its bad debt reserve." ${ }^{29}$ These are precisely the conditions where, as discussed above, the lender needs protection because of the increased probability of debtor misbehavior resulting from the reduced value of the borrower. Even if a loan is still fully secured (as apparently was the case in K.M.C. ${ }^{30}$ ), the rational lender will be concerned that external events and the debtor's incentive to misbehave (for example, by investing in overly risky projects), might jeopardize the lender's position in the future. The actions of the lender in K.M.C., in short, appear to have been perfectly consistent with the purpose of the cessation of funding provision and with the understanding between the parties.

A final difficulty with the notice requirement imposed by the court is that it encourages opportunistic behavior by borrowers, which is precisely what the bonding mechanisms in the loan agreement are designed to avoid. Consider the effect of a notice requirement: Between the time notice

30. Id. at 762 . 
is given by the lender and the time further advances are cut off, the borrower can request funds up to the full amount provided by the letter of credit agreement. These funds can then be used to the detriment of the lender in whatever manner the borrower chooses. ${ }^{31}$ In effect, the notice requirement transforms an agreement from one where the lender had sole discretion over whether to continue funding into one where this discretion is vested in the borrower. Thus the notice requirement obliterates the bonding mechanism designed by the parties.

In the final analysis, the court in K.M.C. erred because, in its eagerness to impose a duty of good faith on lenders, it failed to consider what that duty means. The duty of good faith is best understood as an implied contractual term designed to deter opportunistic behavior. The notice requirement created by the court in K.M.C. cannot be justified under this standard. The evidence suggests not only that the lender in K.M.C. was not behaving opportunistically, but also that the notice requirement will have the reverse effect of encouraging opportunistic behavior by borrowers. As such, the notice requirement as applied in K.M.C. is inconsistent with the intent of the parties (and thus the opposite of an implied contractual term), and will operate to the detriment of both borrowers and lenders.

\section{State National Bank of El Paso v. Farah Manufacturing Co.}

In Farah, the Texas Gourt of Appeals held that a lender acted illegally by threatening to declare an outstanding loan in default pursuant to a management change clause if William Farah returned as C.E.O. Unlike the Sixth Circuit in K.M.C., the court in Farah did not explicitly rely on the duty of good faith to find lender liability. The analysis is nevertheless similar in both cases because, as in K.M.C., the court in Farah again concluded that a lender acted illegally even though its action was seemingly authorized by the underlying agreement. The question thus arises whether the lender in Farah was acting opportunistically by threatening to exercise its right under the management change clause. As in K.M.C., the answer appears to be no.

The situation in Farah was as follows: William Farah became C.E.O. of FMC in 1964. The company was successful and went public in 1967. As a result of a strike and other difficulties, however, the company then experienced serious financial problems. During the period from 1972-76, FMC experienced a pre-tax loss of approximately $\$ 44$ million. In July, 1976, Farah was replaced as C.E.O. Seven months later, in February 1977, FMC and several of its lender banks amended a preexisting loan

31. The court in K.M.C. held that Irving had a good faith obligation to provide notice "absent valid business reasons precluding Irving from doing so." Id. at 759. The court failed to consider the possibility that the risk of opportunistic behavior by the borrower was itself a valid business reason for not providing notice. 
agreement to include a management change clause. The clause made it "an event of default" if there occurred "[a]ny change" in the senior management of FMC that "any two Banks shall consider, for any reason whatsoever, to be adverse to the interest of the Banks." 32 One month later, in March 1977, Farah attempted to return as C.E.O., and the banks resisted the change claiming that it would constitute an act of default. The Texas court deemed this threat by the banks to constitute fraud, duress, and interference with the debtor's business relations. ${ }^{33}$

The court in Farah did not understand the purpose of the management change clause. The clause, like the cessation of funding clause in K.M.C., is best understood as a bonding mechanism used by the borrower to obtain more favorable credit terms. The lenders in Farah attributed the losses between 1972 and 1976 to Farah. These losses, as emphasized throughout, had a dual effect-they increased the risk of default and also the incentive of the debtor to misbehave, thus further increasing default risk. To allay the lenders' concerns, FMC agreed to the management clause which gave the banks veto power over Farah's return as C.E.O. and over any other senior management change; according to the clause, the banks could exercise their power "for any reason whatsoever." When Farah attempted to return as C.E.O. one month after FMC agreed to the management change clause, the banks legitimately protested within the terms of this agreement.

The court's holding in Farah is indefensible. The lenders were not behaving opportunistically-that is, they were not trying to extract from the borrowers a benefit for which they had not originally bargained. On the contrary, the banks' actions were clearly contemplated by the management change clause, which was designed for precisely the contingency in which it was used.

The court tried to escape this conundrum by drawing a distinction between the use of the clause to declare a default and the use of the clause to threaten to declare a default. The evidence did not clearly show whether the lenders had already decided to declare a default if Farah returned or whether they were merely bluffing. But the distinction emphasized by the court is unsatisfactory. First, it is not surprising that there was conflicting evidence as to whether the banks had irrevocably decided to declare an act of default if Farah returned or whether this was still an open question. The decision was an important one for the lenders, and need not have been made final until and unless FMG violated the management change clause. Since the violation had not yet occurred, the lenders were not required to reach a final decision.

32. Farah, 678 S.W.2d at 667 (emphasis added).

33. The aspect of fraud arose when the borrowers questioned the intention of the lenders even to follow through with their stated threat to call the loan if Farah was reinstated as C.E.O. Id. at 781 . See infra pp. 131-32. 
Nor is the court correct in suggesting that the lenders did something wrong by "threatening" to exercise their contractual rights as opposed to waiting and then declaring an act of default. Imagine that the lenders had not communicated to FMC their dissatisfaction with Farah's return and that they had not told FMC that this act would be an event of default under the management change clause. If Farah had then returned and the lenders declared the loan in default, the lenders would be liable under the rationale of K.M.C. for failing to provide notice. Yet, having given notice, the lenders were accused of fraud and duress. The Catch- 22 faced by lenders confronted with these conflicting legal doctrines is obvious.

In sum, both K.M.C. and Farah were wrongly decided. The lenders in both cases acted pursuant to contractual provisions best understood as bonding mechanisms used by borrowers to obtain more favorable credit terms. The application of the duty of good faith in K.M.C. and the analogous judicial exercise in Farah are misplaced because the lenders in both cases were not behaving opportunistically. Rather than deterring opportunistic behavior by lenders, both courts simply eviscerated bonding mechanisms that benefit both borrowers and lenders.

\section{G. A Note on Fiduciary Duties}

Borrowers in lender liability cases also routinely allege that the actions of the lender violated a fiduciary duty owed to the borrower. In the Hunt case, for example, the Hunt brothers alleged that the lenders breached a fiduciary duty owed to them in seeking to collect outstanding loans. ${ }^{34}$ This alleged breach of fiduciary duty, the Hunts claimed, was a defense to the lenders' attempt to collect the unpaid principal and interest. The district court in the Hunt case was skeptical that the lenders owed a fiduciary duty to the Hunts but ruled that the issue was a question of fact not amenable to summary judgment. Another court has suggested that the relationship between a bank and its loan customers may be "quasi-fiduciary" in character. ${ }^{36}$

Imposing a fiduciary duty on lenders is inappropriate in the typical lender liability case. Fiduciary duties govern agency relationships. An agency relationship is an agreement in which one or more persons (the principal[ $s]$ ) delegate authority to another person (the agent) to perform some service or task on the principal's behalf. Examples of agency relationships in commercial contexts include trustees who manage money on behalf of others and corporate directors. In both cases, fiduciary duties require the agent to act on behalf of the principal.

34. Hunt v. Bankers Trust Co. (No. 3-86-1684-H) (N.D. Tex. Mar. 26, 1987) (consolidated with No. 3-86-2012-H).

35. See Barrett v. Bank of Am., N.T. \& S.A., 183 Cal. App. 3d 1362, 1369, 229 Cal. Rptr. 16, 20 (Cal. Ct. App. 1986). See also First Nat'l Bank v. Brown, 181 N.W.2d 178 (Iowa 1970) (finding duty of disclosure based on relationship between bank president and borrower). 
The lender-borrower relationship, however, is not analogous to the principal-agent relationship. In a loan agreement, there is no comparable delegation whereby one party agrees to act on behalf of the other; thus, no agency relationship is created. The relationship is more accurately described as being at arms-length, where both parties act for themselves rather than as agents for each other.

Moreover, even if the common understanding of fiduciary duty could somehow be stretched to encompass lender-borrower relationships, it would still be necessary to define exactly what conduct was required of the lender. Optimal fiduciary rules approximate the bargain that the parties would have reached if the costs of contracting were zero. ${ }^{36}$ Thus, it would make no sense to interpret fiduciary duties so as to prohibit practices, such as the bonding mechanisms at issue in K.M.C. and Farah, that are part of the bargain between borrowers and lenders. To do so would interpret fiduciary duties in a way that penalizes not only lenders but also borrowers, who are the supposed beneficiaries. In other words, even if lenders are deemed to owe a fiduciary duty to borrowers, K.M.C. and Farah would still be wrongly decided.

\section{Damages In Lender Liability Gases}

Thus far I have focused on issues of liability in lender liability cases. In this section I discuss the relevant principles for analyzing damages in these cases. However, my discussion of damages should not deflect attention from the main point that it often should not be necessary to reach this issue if the economics of the lender-borrower relationship are properly understood. Nevertheless, damage issues are critically important because the exposure faced by lenders will greatly influence the number of cases filed and the terms on which cases are resolved.

Damage claims in lender liability cases follow a familiar pattern. A lender is alleged either to have wrongfully refused to lend, or to have called, a loan. The borrower then demands huge actual damages based on lost profits. Juries seem receptive to this demand. In FDIC $v$. Scharenberg, ${ }^{37}$ for example, a jury awarded the plaintiff, a real estate developer, $\$ 105$ million in actual damages based on the alleged improper refusal of Continental Illinois to advance $\$ 3$ million in funds. In the same case, the plaintiffs requested more than $\$ 200$ million in punitive damages based on the same alleged improper refusal by Continental to lend $\$ 3$ million. While no punitive damages were awarded, juries in other cases have not felt so restrained. ${ }^{38}$

36. For an analysis of fiduciary duties along these lines, see Easterbrook \& Fischel, Corporate Control Transactions, 91 YALE L.J. 698 (1982).

37. (Nos. 84-2712, 87-0211, 87-0238) (S.D. Fla. April 29, 1987); see supra note 6.

38. See cases cited supra note 6. 
Economic principles can be used to show why damage measures used in the past have been improperly constructed. I begin this section with a general discussion of the proper methodology for analyzing damages in lender liability cases. I then apply this methodology to Farah and K.M.C.

\section{A. General Principles of Contract Damages}

The relationship between a lender and a borrower is contractual. In contracts cases, courts typically apply the expectations measure of damages once a breach has been found. The goal of the expectations measure is to place the plaintiff in the same position as if the contract had been performed. There are, however, several qualifications on this general statement. One is that under the rule of Hadley $v$. Baxendale consequential damages caused by the defendant's breach can be recovered only if foreseeable. ${ }^{39} \mathrm{~A}$ second qualification is that damages cannot be recovered if the plaintiff could have avoided them with reasonable efforts. ${ }^{40}$

The plaintiff's duty to mitigate damages has particularly important implications in the lender liability context. Consider the situation of a borrower with profitable opportunities who is denied a source of credit. Assume the denial of credit is a clear breach by the lender. Under conventional principles of contract law, the borrower cannot claim the loss of the profitable opportunities as damages flowing from the breach. Rather, the duty to mitigate damages requires the borrower to obtain credit from an alternative source. The borrower's damages should be limited to the cost of cover (i.e., a higher interest rate and/or the transaction costs of negotiating another loan).

It is important to emphasize that dollars are not an idiosyncratic good like a rare painting for which no substitutes exist. On the contrary, dollars are the most fungible of all commodities. Moreover, a wide array of alternative sources of commercial credit exist. Banks, pension funds, insurance companies, investment partnerships, venture capitalists and others are seeking at all times to find profitable opportunities for investment. Brokers who serve to match lenders with worthy borrowers advertise routinely in newspapers and financial publications. It is this widespread availability of alternative sources of credit which provides the rationale for limiting borrowers' damages to the costs of cover rather than lost profits.

Borrowers in lender liability cases typically assert that they were unable to obtain alternative sources of credit. What has not been fully appreciated, however, is the fundamental incompatibility between this claim

39. For a discussion of consequential damages and the forseeability rule of Hadley v. Baxendale, 156 Eng. Rep. 145 (QB 1854), see Epstein, Beyond Forseeability: Consequential Damages in the Law of Contract, 18 J. LEGAL. STUd. 105 (1989).

40. For an economic analysis of the legal rules governing mitigation, see Goetz \& Scott, The Mitigation Principle: Toward a General Theory of Contractual Obligation, 69 VA. L. REv. 967 (1983). 
and the borrower's simultaneous demand for huge damages to make up for lost profits. If a business is really that valuable, market participants would be willing to invest in it-they are leaving money on the table if they don't. Conversely, if nobody is willing to invest, a strong presumption arises that the business was not that valuable in the first place.

Returning to the allegations of Scharenberg $v$. Continental Bank, it is wholly unrealistic to conclude that Continental and all other economic actors in the economy would refuse to lend or otherwise invest $\$ 3$ million in a venture with potential profits of $\$ 100$ million, a rate of return in excess of $3000 \%$. Why should a court believe that there were significant lost profits when the consensus of market participants, equipped with superior expertise and every incentive to make the right decision because their wealth was at stake, concluded the opposite?

\section{B. Complicating Factors: Time Immediacy, the Threat of Bankruptcy and Transaction-Specific Assets}

These simple principles of contract damages will resolve most cases but not all. Some hard cases will remain. The complexity of some businesses and the difficulty of establishing a relationship with a new lender may make it difficult to renegotiate a new loan instantaneously. The time necessary to obtain an alternative source of credit may create difficulties in situations where time is of the essence.

\section{Time Immediacy and The Threat of Bankruptcy}

One situation in which time appears to be of the essence is the case where the borrower needs funds immediately to pay other creditors who have the power to trigger an involuntary bankruptcy. If creditors trigger involuntary bankruptcy after a lender refuses to advance additional funds, the borrower's claim of lost profits may seem more plausible.

But such a claim is still highly suspect. First, the inability of the borrower to have avoided bankruptcy by convincing either existing creditors to wait before filing or other creditors to advance additional funds suggests that there are no huge profits to be lost. Second, even if no pre-bankruptcy solution is negotiated, a credit-worthy debtor should still be able to obtain financing after bankruptcy is triggered.

It is important to recognize that a firm does not automatically lose its going concern value even if it is forced into bankruptcy. Bankruptcy does not cause the borrower's assets and business opportunities to disappear. On the contrary, the debtor can continue its operations after the filing and still obtain financing. Indeed, lenders have a strong incentive to finance bankrupt debtors with sound business opportunities. Under the Bankruptcy Code, a lender that finances a bankrupt debtor can get a super priority whereby prior lenders are subordinated. The availability of the 
super priority for new lenders suggests that bankrupt debtors who have good investment opportunities can obtain financing. This significantly lowers the probability that a refusal to extend credit by the first lender will cause the debtor to lose its going concern value. But there is a more fundamental effect of the super priority available to new lenders-it deters opportunistic behavior by the initial lender. This effect occurs because a lender that triggers an involuntary bankruptcy opportunistically may find its loan subordinated to subsequent lenders. Therefore, the refusal of the initial lender to extend credit under these circumstances must reflect a judgment that the debtor is not economically viable.

\section{Time Immediacy and Transaction-Specific Assets}

The strongest argument for awarding damages in lender liability cases exists in situations involving transaction-specific assets. Assume a purchaser agrees to purchase an office building for $\$ 100$ million on a certain date and arranges to finance the purchase. The purchaser has previously put up $\$ 1$ million in earnest money, which it will forfeit if it cannot raise the $\$ 100$ million on the day of closing. The lender then defaults and the purchaser forfeits the $\$ 1$ million. Since no possibility of cover existed, the purchaser cannot be faulted for failure to mitigate damages. Unless some other limitation on damages applies, such as the foreseeability rule of Hadley v. Baxendale, the purchaser should be able to recover the lost $\$ 1$ million from the lender.

The $\$ 1$ million is recoverable in the above example because it is transaction-specific; it cannot be recovered by engaging in another transaction. The question then arises whether the purchaser should be allowed to recover lost profits in addition to the $\$ 1$ million earnest money. The answer depends on whether or not the claimed lost profits are as transactionspecific as the earnest money deposit. A claim might be made that lost profits should be awarded if the office building was underpriced relative to other assets. This is an unlikely rationale for awarding lost profits, however, because the more natural assumption in an arms-length commercial transaction is that the building is priced so that the purchaser can expect a competitive rate of return (adjusted for risk). ${ }^{41}$

To be sure, the purchaser may have some special expertise that would produce a greater than competitive rate of return if the building were purchased. But even in this case, the purchasers with such skills can buy another office building (few office buildings are truly unique) or attempt to purchase the initial building after it has been sold to someone else.

41. The extent to which a transaction price should be regarded as the best approximation of the value of an asset is a function of many factors, including the sophistication of the buyer and seller, the solicitation of bids in an auction or elsewhere, and the information available to market participants. 
Thus, profits attributable to special skills will likely be earned whether or not the office building is sold to another purchaser.

If the claimed lost profits resulting from failure to purchase the office building are equally available from the purchase of another office building, then the lost profits are not transaction-specific and should not be recoverable. Damages should be limited to the cost of cover-any increase in cost incurred by the purchasers (for example, as a result of rising commercial real estate values) because of the breach by the lender.

\section{The Effects of Damage Windfalls}

The preceding discussion demonstrates that huge damage awards based on lost profits should not routinely be awarded in lender liability cases. In the absence of time immediacy and transaction-specific assets, such awards cannot place the plaintiff in the same position as though the contract had been performed-the goal of the expectation measure of damages. On the contrary, such awards provide the plaintiff with a windfall, making the borrower better off than if no breach had occurred. In addition, an award of punitive damages exacerbates the situation by increasing the size of the windfall even more.

While a particular borrower-plaintiff may benefit from the receipt of such a windfall, borrowers as a class will not. Windfall damage awards create perverse incentives. Since the borrower is better off if the contract is breached than if it is performed (i.e., the expected return in the form of damages exceeds the expected return from the investment), the borrower has an incentive to induce a breach. Similarly, the prospect of a windfall damage award makes the lender reluctant to enforce its contractual rights in response to misbehavior by the borrower. ${ }^{42}$ In sum, windfall damage awards will result in an increase in the amount of debtor misbehavior and a decrease in the protections available to the lender.

Lenders, however, will not bear this increased risk of debtor misbehavior without compensation. If lenders cannot protect themselves by contract from debtor misbehavior, they will charge higher interest rates, to the detriment of borrowers as a class. The impact will be borne disproportionately by high-risk borrowers, such as those with no significant credit history, because bonding mechanisms are likely to be particularly important for this class of borrowers. But if the prospect of huge damage awards eviscerates bonding mechanisms insofar as the borrower can no longer credibly commit to give the lender discretion to discontinue funding, high risk borrowers have less ability to allay lenders' concerns. These borrowers will then have to shift to some alternative and presumptively inferior

42. The perverse incentives created by excessive damage awards explains why punitive damages are not typically awarded for breach of contract. See Cooter, Economic Analysis of Punitive Damages, 56 S. CAL. L. REv. 79 (1982). 
form of credit arrangement or, at the margin, abandon the project altogether. In this event, society as a whole will suffer because valuable investment opportunities are foregone.

\section{Damages in Farah and K.M.G.}

It is now possible to apply the above general principles to the discussion of damages in Farah and K.M.C.

1. State National Bank of El Paso v. Farah Manufacturing Co.

In Farah, damages were calculated for the period between April 1, 1977 through March 31, 1978, the period during which the lenders' alleged wrongfully threatened exercise of the management change clause prevented Farah from returning as C.E.O. The jury found that FMC incurred losses of $\$ 2,668,000$ during this period and lost profits of $\$ 15,482,500$ for total damages of approximately $\$ 18$ million. $^{43}$ Plaintiff's expert caculated lost profits by comparing actual sales and profits from 1959-1975 and then projecting what sales and profits would have been had Farah been in control during the damage period. ${ }^{44}$

The damage award of $\$ 18$ million in Farah appears outrageous even if it is (incorrectly) assumed that the lenders acted improperly in threatening to exercise the management change clause. If FMC believed that Farah would increase profitability by $\$ 18$ million, all it had to do was renegotiate its loan to delete the management change clause. Indeed, that is precisely what was done in April 1978 to facilitate Farah's return. Alternatively, FMC could have negotiated a new loan with a different lender without the management change clause and paid off the existing loan. By not pursuing these options at the time the lenders threatened to exercise the management change clause, FMC failed to mitigate damages. More importantly, it demonstrated by its actions that it believed the "damages" resulting from the threatened exercise of the management change clause were less than the costs of renegotiation. The costs of renegotiation-the cost of cover-should have been the maximum damages awarded.

This conclusion is not affected by the calculation of lost profits by the plaintiff's expert or by the return of FMC to profitability when Farah regained control in 1978. The calculation of lost profits by the plaintiff's expert was meaningless. Any study that tries to forecast profitability for the period 1976-77 by analyzing the profitability of sales from 1959-75 (even assuming this projection was done accurately) is inherently suspect. This suspicion is particularly true under the facts of Farah. Recall that FMC lost large sums from 1972-76 and this was why Farah was re-

43. Farah, 678 S.W.2d at 669 .

44. Id. at 679 . 
placed as CEO and the lenders negotiated for the management change clause. Any forecast should have focused on this more current and reliable period. And, again, the best evidence that the expert's calculations were meaningless is the behavior of FMC itself, which accepted the management change clause and then made no attempt during the damage period to renegotiate or secure alternative financing.

The return to profitability after Farah returned as G.E.O. in 1978 is similarly irrelevant. This renewed profitability may be less attributable to Farah's return than to, for instance, a favorable change in industry conditions. But even if Farah were completely responsible, it still makes no difference. A plaintiff should not be allowed to observe a breach, do nothing and speculate on future events. The proper time to measure damages is between the time of the breach and the time when the plaintiff had a duty to mitigate. Any losses after this point could have been avoided if the plaintiff had taken reasonable care by renegotiating or by obtaining alternative financing.

\section{K.M.C. Co. v. Irving Trust Co.}

The damage testimony and discussion of damages by the court in K.M.C. are equally unpersuasive. There the jury concluded that K.M.C. lost $\$ 7.5$ million in lost profits as a result of the refusal by Irving to advance $\$ 800,000$ in requested funds on March 1, 1982. The jury reached this conclusion even though Irving advanced $\$ 700,000$ of the $\$ 800,000$ on March 4, just 3 days later. ${ }^{45}$ Thus the jury apparently concluded that K.M.C.'s value declined by $\$ 7.5$ million as a result of a three-day delay in funding.

The jury reached this conclusion based on testimony by two of plaintiff's experts, who testified that the value of K.M.C. to potential acquirors was reduced by $\$ 10$ million or more by Irving's refusal to advance the $\$ 800,000$ on March $1 .{ }^{48}$ This testimony is inherently incredible. Why should the value of K.M.C. fall by more than $\$ 10$ million because of the lack of availability of funds for three days? During this three day period, K.M.C. had $\$ 800,000$ less money but it also owed $\$ 800,000$ less. The failure to borrow money is a wash. There is no suggestion in the court's opinion that some unique investment opportunity was lost to K.M.C. or that some unique asset necessary to the continuation of the business was lost during this three day period.

Absent such evidence of a lost unique economic opportunity, the damages consist of the loss of good will caused by the unavailability of funds for a three day period. This amount is likely to be trivial, particularly for a firm like K.M.C. which was already highly leveraged and in financial 
distress: If potential acquirors were interested in a firm with these characteristics prior to March 1, there is no reason to believe that anything would change because the lender failed to advance funds for three days. At the very least, it is wholly implausible to conclude, as one of plaintiff's experts did, that an acquiror would have paid $\$ 10$ million on March 1 but nothing thereafter. ${ }^{47}$ The trial court should have thrown out a verdict based on such testimony.

Thus the analyses of damages by the courts in Farah and K.M.C. are fundamentally flawed. An understanding of the economics of contract damages would have led to a different result in both cases.

\section{Conclusion}

In recent years, the booming area of lender liability has dramatically increased the exposure faced by lenders. The doctrines of liability and damages that have evolved in the lender liability area, however, are frequently based on a misunderstanding of basic economic principles. Once these principles are understood, the exposure faced by lenders should radically decrease. The resulting incentive structure operating on lenders and borrowers should promote efficient terms in loan contracts.

47. Id. at 765 . 